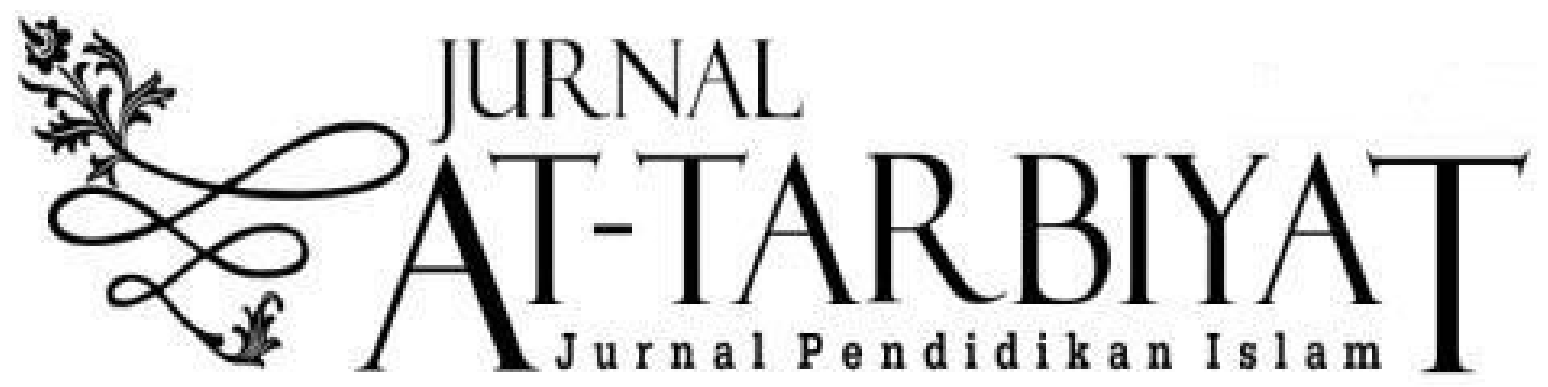




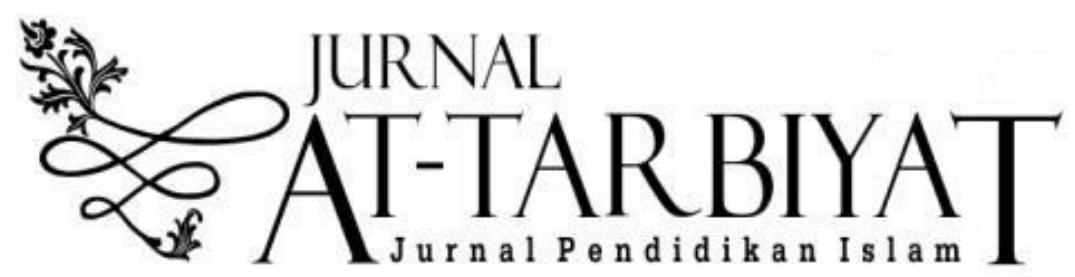

Editorial Team:

Editor in-Chief

Adi Wibowo, STAI An- Nawawi

Purworejo

\section{Editorial Board}

Badrudin, UIN Sunan Gunung Djati Bandung

Imam Machali, UIN Sunan Kalijaga Yogjakarta

Sri Rahmi, UIN Ar-Raniry Banda Aceh

A.Jauhar Fuad, IAI Tribakti Kediri

\section{Managing Editor}

Muhlil Musolin, STAI An- Nawawi

Purworejo

\section{Editor}

Ita Nurmala Sari, STAI An- Nawawi

Purworejo

Ahmad Syafi'i, UIN Sunan Kalijaga

Yogjakarta

Ulumuddin, Unwahas Semarang

Dwi Puji Lestari, STAI Al Hasyimiyyah Jakarta

Sri Sujarotun, STAI An- Nawawi Purworejo

Ali Murfi, UIN Sunan Kalijaga Yogjakarta

\section{Editorial Assistant}

Isnaini, STAI An- Nawawi Purworejo

Mujasim, STAI An- Nawawi Purworejo

\section{Alamat Redaksi:}

Prodi Manajemen Pendidikan Islam, STAIAN Purworejo

Jl. Ir.H. Juanda No. 1 Berjan, Gebang Purworejo 54191 Jawa Tengah»

Tel / fax : (0275)3128428. e-mail: jurnalattarbiyat@gmail.com http://jurnal.staiannawawi.com/index.php/At-Tarbiyat 


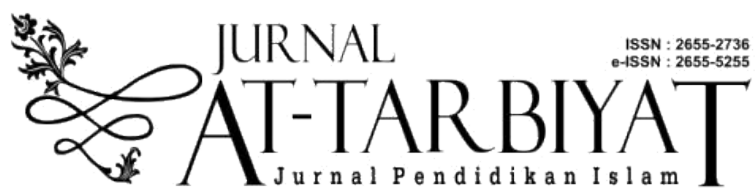

http://jurnal.staiannawawi.com/index.php/At-Tarbiyat

\title{
Pengaruh Program Pendidikan dan Pelatihan terhadap Peningkatan Kompetensi Guru di SMP Negeri 1 Keritang
}

\author{
Hardiyanti, Irawati, Hasgimianti, Nurhayati Zein, Musa Thahir \\ Universitas Islam Negeri Sultan Syarif Kasim, Indonesia \\ Hardynti30@gmail.com \\ irawati@uin-suska.ac.id \\ hasgimianti@uin-suska.ac.id
}

\section{Abstrak}

Pendidikan dan pelatihan memberikan kesempatan pada guru untuk meningkatkan prestasi pembelajaran di sekolah. Penelitian dimaksudkan untuk dapat mengetahui pengaruh program pendidikan dan pelatihan terhadap peningkatan kompetensi guru serta untuk mengetahui faktor-faktor yang dapat mempengaruhi kedua variable tersebut. Penelitian ini dilakukan untuk mengetahui seberapa besar pengaruh program pendidikan dan pelatihan terhadap peningkatan kompetensi guru yang berada di SMP Negeri 1 Keritang. Penelitian ini merupakan penelitian kuantitatif dengan jenis penelitian korelasi dengan menggunakan teknik analisis regresi linier sederhana. Variabel bebas (X) Program pendidikan dan pelatihan, variabel terkait (Y) Peningkatan kompetensi. Dengan subjek penelitian sebanyak 30 orang guru SMP Negeri 1 Keritanng dengan menggunakan total sampling. Analisis data dibantu dengan menggunakan SPSS 22.0 . Hasil penelitian menunjukan bahwa (1) program pendidikan dan pelatihan berada pada kategori sangat baik dengan persentase 83\%, (2) peningkatan kompetensi berada pada kategori sangat baik dengan persentase 86\%, (3) terdapat pengaruh signifikan antara program pendidikan dan pelatihan terhadap peningkatan kompetensi guru di SMP Negeri 1 Keritang dengan nilai rhitung 0,776 lebih besar dari rtabel pada taraf signifikan 5\% yaitu 0,361 $(0,776>0,361)$. Jadi dalam penelitian ini dapat disimpulkan bahwa semakin baik program pendidikan dan pelatihan maka semakin berkualitas pula peningkatan kompetensi guru. Sekolah diharapkan untuk dapat meningkatkan efektifitas pelaksanaan program pendidikan dan pelatihan agar peningkatan kompetensi guru terus mengalami peningkatan dengan lebih baik.

Kata Kunci: Program Pendidikan dan Pelatihan, Kompetensi Guru 
Education and training provide opportunities for teachers to improve learning achievement in schools. The research is intended to determine the effect of education and training programs on increasing teacher competence and to find out the factors that can affect both of these variables. This research was conducted to find out how much influence the education and training program has on increasing teacher competency in SMP Negeri 1 Keritang. This research is a quantitative study with the type of correlation research using simple linear regression analysis techniques. Independent variable $(X)$ Education and training program, related variable $(Y)$ Competency improvement. With research subjects as many as 30 teachers of SMP Negeri 1 Keritanng using total sampling. Data analysis was assisted using SPSS 22.0. The results showed that (1) the education and training program was in the very good category with a percentage of $83 \%$, (2) the increase in competency was in the very good category with a percentage of $86 \%$, (3) there was a significant influence between the education and training program on competency improvement the teacher in SMP Negeri 1 Keritang with a $r$ value of 0.776 is greater than rtable at a significant level of $5 \%$, that is $0.361(0.776>0.361)$. So in this study it can be concluded that the better the education and training program, the better the quality of teacher competency improvement. Schools are expected to be able to increase the effectiveness of the implementation of education and training programs so that teacher competency improvement continues to increase better.

Keywords: Education and Training Programs, Teacher Competencies

\section{PENDAHULUAN}

Dunia pendidikan saat ini mengalami berbagai tantanga, salah satunya yaitu ilmu pengetahuan dan teknologi terus mengalami perkembangan dengan cepat. Masyarakat saat ini dituntut menjadi manusia yang lebih berkualitas tinggi, memiliki wawasan luas dengan seluruh keterampilan yang dimiliki. Untuk menghadapi tantangan ini maka dituntut untuk terus mempersiapkan sumber daya manusia yang kompeten agar bisa bersaing. Sumber daya manusia merupakan sumber daya organisasi selain dari sumber daya modal.

Seiring perkembangan bidang pengetahuan dan teknologi, maka setiap organisasi dapat memanfaatkan, menerapkan, dan mengelola sumber daya dengan baik. Dalam dunia pendidikan guru merupakan suatu profesi yang memiliki kedudukan, peran, 
dan fungsi yang strategis dalam pembangunan nasional. Seperti yang di sebutkan dalam undang-undang "pembangunan nasional pendidikan merupakan upaya mencerdaskan kehidupan bangsa dan meningkatkan kualitas sumber daya manusia indonesia yang beriman, bertakwa, dan berakhlak mulia dan menguasai ilmu pengetahuan, teknologi, dan seni dalam mewujudkan masyarakat yang maju, adil, makmur, dan beradab".

Pada saat ini manajemen sumber daya manusia dipandang penting oleh semua pihak, karena sumber daya manusia memiliki pengaruh yang besar terhadap efektifitas dan efesiensi organisasi dibandingkan dengan sumber daya lainnya. Sumber daya manusia harus di kelola dengan baik untuk menentukan pencapaian tujuan dan kesuksesan organisasi. Apabila tidak mengelola sumber daya manusia dengan baik maka efektifitas dan efesiensi organisasi tidak akan tercapai. Oleh karena itu, bagian yang sangat penting dari tugas manajemen organisasi adalah pengelolaan sumber daya manusia yang baik. ${ }^{1}$

Dalam sebuah organisasi lembaga pendidikan guru merupaka sumber daya manusia utama dengan melihat peranan guru yang sangat penting bagi generasi bangsa, profesi guru adalah suatu profesi yang profesional dengan tugas mendidik peserta didiknya. Seperti yang di jelaskan dalam Undang-Undang Republik Indonesia tentang guru dan Dosen pada pasal 1 ayat 1 . "Guru yaitu pendidik professional yang memiliki tugas utama mengajar, mendidik, membimbing, melatih, mengarahkan, menilai, dan mengevaluasi peserta didik dipendidikan anak usia dini jalur pendidikan formal, pendidikan dasar, dan pendidikan menengah". ${ }^{2}$

Seorang pendidik seharusnya berkembang setiap saat sesuai dengan perkembangan pengetahuan, teknologi, dan juga masyarakat. Ilmu pengetahuan, keterampilan, dan sikap ataupun kompetensi pendidik dalam menentukan proses pembelajaran yang dilaksanakan dalam kelas dan pendidikan di sekolah.

Fungsi manajemen sumber daya manusia diantaranya adalah untuk menentukan bentuk pendidikan atau pelatihan dan perkembangan pegawai/karyawan, untuk menempatkan nya

1 Tuti Andriani, Manajemen SDM dalam Pendidikan,(Bogor: Education mattersmost publishing. 2013). hlm. 10.

${ }^{2}$ Undang-undang Republik Indonsia No. 14 Tahun 2005 Tentang Guru dan dosen,(Yogyakarta: Pustaka Mahardika, 2015). hlm. 3.

175 Vol. 2, No. 2, Juli - Desember 2019 
dalam suatu lingkungan kerja yang produktif dan memberikan balas jasa (reward) atas pertasi kerjanya. ${ }^{3}$

Pelatihan memiliki fungsi yang berpengaruh sangat signifikan terhadap efektifitas sebuah sekolah. Guru mendapat kesempatan untuk mengembangkan keterampilan, ilmu pengetahuan, dan sikap baru pada peningkatkan prestasi belajar siswa dari sebuah pelatihan. ${ }^{4}$ Dalam konteks pengembangan sumber daya manusia, pendidikan dan pelatihan merupakan upaya untuk mengembangkan sumber daya manusia, terutama dalam hal mengembangkan kemampuan intelektual dan kepribadian bangsa. ${ }^{5}$

Pelatihan merupakan sebuah proses peningkatan keterampilan dan pengetahuan pegawai. Pelatihan juga merupakan pembentukan sikap sehingga pegawai dapat melakukan pekerjaan nya lebih efektif. ${ }^{6}$ Pendidikan yakni usaha sadar terencana yang dapat menjadikan suasana belajar serta proses pembelajaran secara aktif agar dapat mengembangkan potensi, keterampilan, dan kemampuan seseorang.

Mulyasa menjelaskan pengembangan guru dapat dilakukan dengan cara on the job training dan in service training, model "training" ini merupakan model pengembangan yang banyak dilakukan oleh lembaga pendidikan. Model pengembangan guru melalui pelatihan yakni adanya teknik dan perilaku yang pantas untuk ditiru kedalam kelas. ${ }^{7}$ Sedangkan Kunartinah menjelaskan, bahwa pendidikan pada dasarnya dimaksudkan untuk mempersiapkan sumber daya manusia sebelum memasuki pasar kerja. Dengan pengetahuan yang diperoleh dari pendidikan dalam proporsi tertentu diharapkan sesuai dengan syarat-syarat yang dituntut oleh suatu pekerjaan. ${ }^{8}$

Jadi dapat diketahui bahwa Pendidikan dan pelatihan merupakan suatu sarana atau wadah untuk pemantapan

3 Pandi Afandi, Manajemen Sumber Daya Manusia, Teori, Konsep dan Indikator,(Pekanbaru: Zanafa Publishing, 2018). hlm. 127.

4 Jejen Musfah, Peningkatan Kompetensi Guru: Melalui Pelatihan dan Sumber Belajar Teori Praktik, (Jakarta: Kencana, 2011). hlm. 61.

5 Ibid, hlm. 128.

${ }^{6}$ Kaswan, Pelatihan dan Pengembangan; untuk meningkatkan kineja SDM, (Bandung: Alfabeta, 2013), hlm. 2.

7 Udin Syaefudin Saud, Pengembangan Profesi Guru, (Bandung : Alfabeta, 2013). hlm. 98-102.

${ }^{8}$ Kunartinah, "Pengaruh Pendidikan Dan Pelatihan, Pembelajaran Organisasi Terhadap Kinerja Dengan KOmpetensi Sebagai Mediasi,” Jurnal Bisnis Dan Ekonomi (JBE) Vol. 17, no. 01 (2010): 1.

176 Vol. 2, No. 2, Juli - Desember 2019 
kemampuan, pengetahuan, wawasan, dan kecakapan pegawai akan peran dan fungsinya didalam organisasi.

Pertanyaan dalam penelitian ini adalah Seberapa besar pengaruh pendidikan dan pelatihan terhadap peningkatan Kompetensi guru di SMPN 1 Keritang?. Penelitian ini bertujuan Untuk mengetahui besarnya pengaruh program pendidikan dan pelatihan terhadap peningkatan Kompetensi guru di SMPN 1 Keritang.

\section{Metode Penelitian}

Penelitian yang dilakukan merupakan penelitian kuantitatif dengan jenis penelitian korelasi. Metode kuantitatif ini dapat diartikan sebagai metode penelitian yang berlandaskan pada filsafat positivisme, digunakan untuk meneliti pada populasi atau sampel tertentu, pengumpulan data menggunakan instrumen penelitian, analisis data bersifat kuantitatif atau statistik. Dengan tujuan untuk menguji hipotesis yang telah ditetapkan. ${ }^{9}$ Penelitian ini dilakukan pada bulan Agustus sampai dengan oktober 2019 dan penelitian berlokasi dilaksanakan di Sekolah Menengah Pertama Negeri 1 Keritang.

Adapun Subjek penelitian ini adalah seluruh guru di SMP Negeri 1 Keritang. Dengan jumlah populasi keseluruhannya 30 orang, dalam penelitian ini menggunakan total sampling dengan alasan bahwa populasi kurang dari 100 orang, yaitu hanya berjumlah 30 orang saja, maka seluruh populasi dijadikan sampel.

Data dalam penelitian ini dikumpulkan menggunakan angket (instrument) yang dilakukan dengan cara memberi seperangkat pertanyaan atau pernyataan tertulis kepada responden untuk dijawabnya. Teknik analisis data penelitian ini menggunakan teknik kuantitatif. Analisis ini digunakan untuk mengetahui adakah korelasi antara pengaruh program pendidikan dan pelatihan terhadap peningkatan kompetensi guru di SMPN 1 Keritang menggunakan teknik analisis Regresi Linier Sederhana. Analisis regresi ini digunakan untuk memprediksi pengaruh variabel bebas terhadap variabel terikat. Analisis regresi linier sederhana terdiri dari satu variabel dependent dan satu variabel independent. ${ }^{10}$

${ }^{9}$ Sugiyono, Metode penelitian Kuantitatif, Kualitatif, dan R\&D,(Bandung: Alfabeta, 2017). hlm. 8.

10 Hartono, SPSS 16.0 Analisis Data Statistik dan Penelitian,(Yogyakarta: Pustaka Pelajar, 2008). hlm. 9. 


\section{Pembahasan}

\section{Program Pendidikan dan Pelatihan}

Pendidikan dan pelatihan merupakan usaha peningkatan sumber daya manusia yakni dengan memberikan wadah pada seseorang untuk mengembangkan tingkat pengetahuan dan keterampilannya pada pelaksanaan tugas serta wewenangnya sesuai dengan pekerjaannya. Notoatmojo dalam Choliq menerangkan bahwa "pendidikan dan pelatihan merupakan salah satu bentuk dari investasi". Oleh karenanya suatu organisasi atau instansi yang ingin berkembang, maka pendidikan dan pelatihan bagi karyawan harus mendapat perhatian khusus. Pentingnya pendidikan dan pelatihan bagi suatu organisasi antara lain sebagai berikut:

1. Sumber daya manusia atau karyawan yang menempati suatu jabatan tertentu dalam organisasi, belum tentu mempunyai kemampuan sesuai dengan persyaratan yang diperlukan dalam jabatannya itu.

2. Adanya kemajuan dalam bidang ilmu teknologi, maka dapat mempengaruhi suatu organisasi tertentu. Oleh karenanya perlu dilakukan peningkatan kemampuan oleh jabatan.

3. Promosi bagi seorang pegawai sangat penting sebagai salah satu reward dan insentif (ganjaran atau perangsang). Terkadang kemampuan seseorang yang akan dipromosikan untuk menduduki suatu jabatan masih belum cukup maka diperlukan pendidikan dan pelatihan.

4. Dalam masa pembangunan ini organisasi atau instansi, baik pemerintah maupun swasta merasa terpanggil untuk menyelenggarakan pelatihan bagi karyawan agar memperoleh efektifitas dan efesiensi sesuai dengan masa pembangunan. ${ }^{11}$

Tujuan pendidikan dan pelatihan pada umumnya di adakan untuk meningkatkan kualitas sumberdaya manusia yakni meningkatkan pengetahuan, keterampilan, motivasi dan sikap, serta kompetensi agar setiap individu dapat melaksankan tugas serta tanggung jawabnya sesuai dengan pekerjaannya.

\section{Kompetensi Guru}

Charles bersama Mulyasa mengatakan kompetensi adalah perilaku rasional untuk mencapai suatu tujuan yang disyaratkan sesuai dengan kondisi yang diinginkan. Sedangkan didalam undang-undang guru dan dosen dijelaskan "kompetensi adalah seperangkat pengetahuan, keterampilan, dan perilaku yang harus 
dimiliki, dihayati, dan dikuasai oleh guru atau dosen dalam melaksanakan tugas keprofesionalan."12

Didalam perspektif kebijakan nasional, pemerinatah telah merumuskan empat kompetensi guru, yang tercantum dalam Undang-Undang Guru dan Dosen yakni "Standar kompetensi guru dikembangkan secara utuh kedalam empat kompetensi, yaitu: kompetensi pedagogik, kompetensi kepribadian, kompetensi sosial, dan kompetensi professional". 13

\section{Program Pelaksanaan Pengembangan Profesionalisme Guru}

Direktorat Jendral Pendidikan Dasar dan Menengah Departemen Pendidikan Nasional (2005) menyebutkan beberapa alternatif Program Pengembangan Profesionalisme Guru, sebagai berikut:

1. Program Peningkatan Kualifikasi Pendidikan Guru

Peningkatan kualifikasi guru dijelaskan dalam UndangUndang Sisdiknas pasal 42 ayat (1) menyebutkan bahwa pendidikan harus memiliki kualifikasi minimun dan sertifikasi sesuai dengan jenjang kewenangan mengajar, sehat jasmani dan rohani, serta memiliki kemampuan untuk mewujudkan tujuan pendidikan nasional. Dan undang-Undang Guru dan Dosen dalam pasal 8 menyebutkan bahwa guru wajib memiliki kualifikasi akademik, kompetensi, sertifikat pendidikan, sehat jasmani dan rohani, serta memiliki kemampuan untuk mewujudkan tujuan pendidikan nasional. sementara itu, Undang-Undang yang sama, pasal 9 menyebutkan kualifikasi akademik yang dimaksud dalam pasal 8 diperoleh melalui pendidikan tinggi program sarjana atau program diploma 4 . Peningkatan kualifikasi dilakukan melalui pendidikan konvensional, pendidikan dalam Universitas Terbuka, pendidikan jarak jauh pendekatan ICT, dan pendidikan jarak jauh pola PKG. ${ }^{14}$

2. Program Penyetaraan dan Sertifikasi

Program penyetaraan dan sertifikasi diperlukan oleh guru yang pelaksaan proses pembelajarannya belum sesuai dengan latar belakang pendidikannya, atau tidak berasal dari program pendidikan guru. Tidak dipungkiri keadaan seperti ini dikarenakan keterbatasan ataupun kelebihan tenaga pendidik

12 Mulyasa, Standar Kompetensi dan Sertifikasi Guru,(Bandung: PT Remaja Rosdakarya, 2009). hlm. 25.

13 Undang-Undang Nomor 14 Tahun 2005 Tentang Guru dan Dosen Pasal I Ayat (1)

14 Barnawi dan Mohammad arifin, Etika dan Profesi Kependidikan,(Jogjakarta: ArRuzz, 2012). hlm. 17-18.

179 Vol. 2, No. 2, Juli - Desember 2019 
dalam suatu sekolah. Misalnya memiliki ijazah S1 tapi bukan dari kependidikan, maka bisa mengikuti program penyetaraan atau sertifikasi. Sertifikasi guru adalah proses perolehan sertifikat pendidik bagi guru. Berdasarkan Permendiknas No. 11 Tahun 2011, sertifikasi dilaksanakan melalui: (a) penilaian portofolio; (b) pendidikan dan pelatihan profesi guru; (c) pemberian sertifikat pendidik secara langsung; atau (d) pendidikan profesi guru. ${ }^{15}$

3. Program Pelatihan Terintegrasi Berbasis Kompetensi

Diperluka pelatihan guna meningkatkan profesionalisme guru, program pelatihan yang diusulkan adalah pelatihan yang sesuai dengan kebutuhan guru, yaitu mengacu kepada tuntutan kompetensi. Selama ini pelaksanaan pelatihan bersifat persial dan pengembangan materi seringkali tumpangtindih, menghabiskan banyak waktu, tenaga,biaya dan kurang efisien. Tidak jarang dalam satu tahun seorang guru mengikuti tiga jenis pelatihan sehingga mengganggu kegiatan PMB, sebaliknya tidak sedikit guru yang tidak pernah mengikuti pelatihan sekalipun dalam setahun. Oleh karena itu pelatihan yang diusulkan adalah Pelatihan Terintegrasi Berbasis Kompetensi, yaitu pelatihan yang mengacu kepada kompetensi yang akan dicapai dan diperlukan oleh peserta didik, sehingga isi atau materi pelatihan yang akan dilatih secara utuh diperlukan untuk mencapai kompetensi. ${ }^{16}$

4. Program Supervisi Pendidikan

Masih ditemui pernyataan yang salah atau kurang tepat mengenai tugas dari supervisor yang diartikan untuk mencari atau mengendalikan tugas guru, sebenarnya bertujuan untuk dapat meningkatkan efisiensi dan efektivitas dari proses belajar mengajar. Saat praktik pembelajaran dalam kelas masih ditemukan guru yang ditingkatkan profesionalitasnya dalam proses belajar mengajar. Ciri utama supervise yakni perunbahan kea rah yang lebih baik, positif, dan proses belajar mengajar menjadi lebih efektif dan efesien. ${ }^{17}$

5. Program Pemberdayaan MGMP

Program ini berfungsi sebagai tempat ataupun sarana berkomunikasi, konsultasi, dan bertukar pengalaman, juga sebagai peningkatan kemampuan dalam menyusun perangkat pembelajaran, pengetahuan, peningkatan wawasan, serta pemahaman guru terhadap materi yang diajarkan. Dengan 
MGMP ini guru dapat berdiskusi tentang masalah yang dihadapi dalam melaksanakan tugas sehari-hari dan mencari penyelesaiannya sesuai dengan karakteristik mata pelajaran, kemampuan siswa, kondisi sekolah dan lingkungan. Kegiatan ini juga menumbuhkan semangat untuk dapat meningkatkan kemampuan dan juga keterampilan guru dalam mempersiapkan, melaksanakan, dan mengevaluasi kegiatan belajar mengajar.

6. Simposium Guru

Simposium merupakan suatu forum yang dijadikan sebagai tempat untuk berbagi pengalaman dalam memecahkan masalah yang terjadi atau dialami dalam proses pembelajaran. Melalui forum ini diharapkan pada para guru untuk dapat menyebarluaskan upaya kreatif dalam memecahkan masalah. Selain itu juga sebagai media untuk sharing pengalaman simposium serta berfungsi sebagai kompetisi antar guru, dengan menampilkan guru yang berprestasi dalam berbagai bidang. Misalnya dalam penggunaan metode pembelajaran, hasil penelitian tindakan kelas atau karya ilmiah. ${ }^{18}$

7. Berpartisipasi dan Aktif dalam Organisasi Profesi

Ikut serta menjadi anggota organisasi atau komunitas profesional akan meningkatkan profesionalisme guru. Organisasi atau komunitas profesional biasanya melayani anggotanya untuk dapat mengembangkan dan memelihara profesionalismenya dengan membangun hubungan yang erat dengan masyarakat (swasta, industri, dan sebagainya). Dalam hal ini yang terpenting adalah guru harus mampu memilih suatu bentuk organisasi profesional yang dapat memberikan manfaat utuh bagi dirinya melalui bentuk investasi waktu dan tenaga. ${ }^{19}$

8. Melakukan Penelitian (Khususnya Penelitian Tindakan Kelas)

Penelitian tindakan kelas ini merupakan studi sistematik yang dapat dilakukan guru melalui kerjasama atau tidak dengan ahli pendidikan dalam rangka merefleksikan dan juga sekaligus meningkatkan strategi yang tepat untuk meningkatkan profesionalisme guru. Berbagai kajian yang bersifat reflektif oleh guru yang dilakukan untuk meningkatkan kemantapan rasional, memperdalam pemahaman terhadap tindakan yang dilakukan dalam melaksanakan tugasnya, dan memperbaiki kondisi dimana praktik pembelajaran berlangsung akan bermanfaat sebagai inovasi pendidikan. ${ }^{20}$

9. Berpartisipasi dalam Pertemuan Ilmiah

\footnotetext{
18 Ibid.,

${ }^{19}$ Ibid., hlm. 110.

${ }^{20}$ Ibid., hlm. 109.

181 Vol. 2, No. 2, Juli - Desember 2019
} 
Kegiatan ini bisa dilaksanakan oleh setiap guru secara mandiri, yang diperlukan hanya bagaimana motivasi dalam dirinya untuk berpartisipasi dalam berbagai pertemuan ilmiah. Konferensi atau pertemuan ilmiah dapat memberikan arti penting dalam menjaga hal mutakhir yang berkaitan dengan profesi guru. Guru minimal ikut berpartisipasi dalam kegiatan mengikuti konferensi atau juga pertemuan ilmiah setiap tahunnya yang akan memberikan kontribusi berharga dalam membangun profesionalisme guru dalam melaksanakan tanggung jawabnya. ${ }^{21}$

\section{Hasil Analisis Data}

Hasil penelitian ini menunjukan seberapa besar pengaruh program pendidikan dan pelatihan terhadap kompetensi guru. Hasil tersebut dapat dilihat dari langkah - langkah sebagai berikut:

\section{Uji Normalitas Data}

Tujuan uji data ini untuk mengetahui data yang berdistribusi normal atau tidak. Maka untuk menguji normalitas data ini peneliti menggunakan bantuan program SPSS 22. Cara yang digunakan untuk mengetahui normal atau tidaknya data adalah jika nilai signifikansi $>0.05$ maka data berdistribusi normal dan jika nilai signifikansi $<0.05$, maka data tidak berdistribusi normal. Berdasarkan perhitungan data yang dilakukan dengan one sample kolmogorov smirnov test maka diketahui bahwa nilai signifikansi sebesar 0,200>0,05, jadi dapat disimpulkan bahwa data berdistibusi normal.

\section{Uji Linearitas Data}

Uji linearitas digunakan untuk mengetahui kelinearan data sebagai prasyarat data dalam pengujian statistik lebih lanjut. Hipotesis yang diuji adalah, Ho : Distribusi data yang diteliti tidak mengikuti bentuk linear, Ha : Distribusi data yang diteliti mengikuti bentuk linear. Dengan dasar pengambilan keputusan sebagai berikut: Jika probabilitas $<0,05=$ Ha diterima dan Jika probabilitas $>0,05=$ Ha ditolak. Berdasarkan hasil perhitungan uji linearitas diperoleh $\mathrm{f}$ hitung $=42,290$ dengan tingkat probabilitas $(\mathrm{sig})=0.000$. Karena probabilitas $0,000<0,05$ maka distribusi data yang diteliti mengikuti bentuk linear (Ho ditolak, Ha diterima). Dengan demikian data tersebut dapat digunakan untuk memprediksi hubungan antara kedua variabel dengan menggunakan regresi linear sederhana. 


\section{Pengujian Signifikansi Pengaruh Program Pendidikan dan Pelatihan terhadap Peningkatan Kompetensi Guru}

Pengujian hipotesis penelitian dilakukan dengan menggunakan analisis regresi linear sederhana, karena terdiri dari satu variabel dependen dan satu variabel independen. Analisis akan digunakan untuk dapat mengetahui pengaruh dari variabel dependen dengan variabel independen, apakah variabel independen berhubungan positif atau negatif juga untuk memprediksi nilai dari variabel dependen apakah mengalami kenaikan atau penurunan. Untuk mengetahui hasil pengujian data dengan menggunakan regresi linear sederhana, peneliti menggunakan bantuan SPSS 22.0. Maka didapat persamaan regresi linear sederhana sebagai berikut:

$\mathrm{Y}=\mathrm{a}+\mathrm{bX}$

$\mathrm{Y}=11,361+0,776 \mathrm{X}$

Dari hasil perhitungan diperoleh $\mathrm{b}=0.776$ bertandakan positif, artinya: Setiap kali variabel X (Program Pendidikan dan Pelatihan) bertambah satu, maka rata-rata variabel $Y$ (Peningkatan Kompetensi) bertambah 0,776. Dengan demikian jika mengikuti program pendidikan dan pelatihan maka peningkatan kompetensi guru akan meningkat sebanyak 0,776.

Dan didapatlah bahwa $r_{\text {hitung }}(0,776)>r_{\text {tabel }}(0,361)$ mengandung arti regresi antara kedua variabel sangat kuat. Berdasarkan tabel tersebut didapatlah nilai koefisien determinasi ( $R$ Square) sebesar 0,602. Ini menunjukan bahwa pengaruh variabel independen terhadap variabel dependen adalah sebesar 60\%. Sedangkan sisanya 40\% (100\%-60\%) dipengaruhi oleh variabel lain yang tidak dimasukkan dalam penelitian ini. Dengan demikian , hipotesis yang berbunyi diduga ada pengaruh program pendidikan dan pelatihan terhadap peningkatan kompetensi guru "diterima".

Hasil penelitian ini diperkuat oleh hasil penelitian terdahulu yang mengatakan bahwa pelatihan secara parsial berpengaruh positif dan signifikan terhadap profesionalitas guru. ${ }^{22}$ Lebih lanjut, hasil penelitian ini sejalan dengan apa yang telah dikemukakan oleh Mulyawan bahwa pentingnya upaya meningkatkan professional guru. Baik secara kualitatif maupun kuantitatif yang perlu dilakukan terus menerus, sehingga kegiatan pelatihan merupakan instrumen penunjang profesionalisme

22 B Mulyawan, "Pengaruh Pelatihan Dalam Pengalaman Terhadap Peningkatan Kompetensi Profesional Guru,” Jurnal Ilmiah Ilmu Sosial Vol.11, no. 01 (2012): 45-64. 
profesi guru dalam menjalankan kinerjanya. ${ }^{23}$ Program pendidikan dan pelatihan mempengaruhi profesionalitas guru. Berdasarkan analisis deskriptif persentase untuk variabel program pendidikan dan pelatihan dalam kategori baik, artinya program pendidikan dan pelatihan yang diikuti guru sudah baik, dan hal tersebut berpengaruh terhadap peningkatan kompetensi guru menjadi lebih baik. Dengan sering mengikuti program pendidikan dan pelatihan yang relevan sesuai dengan kebutuhan guru dapat meningkatkan kompetensi guru. Ini berarti program pendidikan dan pelatihan merupakan bagian yang tidak terpisahkan dari kompetensi.

\section{Simpulan}

SMP Negeri 1 Keritang memiliki susunan personalia dalam pengelolaan sekolah seperti kepala sekolah, komite sekolah, bidang humas, tata usaha, kurikulum, dan sarana prasarana. Jumlah keseluruhan tenaga pendidik dan kependidikan di SMP Negeri 1 Keritang ada 34 orang yg didalam ada kepala sekola, tata usaha, majelis guru, pustakawan dan penjaga sekolah. pada penelitian populasinya yakni semua majelis guru yang berjumlah 30 orang dengan menggunakan Total Sampling, karena semua populasi dijadikan sampel penelitian. Dengan teknik analisis datanya menggunakan teknik Regresi Linear Sederhana, untuk memprediksi pengaruh variabel bebas terhadap variabel terkait.

Berdasarkan hasil penelitian, dapat disimpulkan adanya pengaruh yang signifikan diantara program pendidikan dan pelatihan terhadap peningkatan kompetensi guru di SMP Negeri 1 Keritang, dengan nilai korelasi sebesar 0,776. Hal ini dibuktikan dengan uji korelasi dengan nilai $r_{\text {hitung }} 0,776$ lebih besar dari $r_{\text {tabel }}$ pada taraf signifikan $5 \%$ yaitu $0,361 \quad(0,776>0,361)$. Hasil perhitungan koefisien determinasi ( $R$ Square) sebesar 0,602. Hal ini menunjukkan bahwa pengaruh program pendidikan dan pelatihan terhadap peningkatan kompetensi guru adalah sebesar $60 \%$. Sedangkan sisanya 40\% (100\%-60\%) dipengaruhi oleh variabel lain yang tidak dimasukkan dalam penelitian ini. Dengan demikian, semakin tinggi program pendidikan dan pelatihan maka semakin tinggi pula peningkatan kompetensi guru di SMP Negeri 1 Keritang. 


\section{REFERENSI}

Afandi Pandi. Manajemen Sumber Daya Manusia, Teori, Konsep dan indikator.Pekanbaru: Zanafa Publishing. 2018.

Andriani Tuti. Manajemen SDM Dalam Pendidikan, Bogor: Educationmattersmost Publishing. 2013.

Barnawai, Arifin Mohammad. Etika dan Profesi Kependidikan. Jogjakarta: Ar-Ruzz Media. 2012.

Hartono. SPSS 16.0 Analisis Data Statistik dan Penelitian.Yogyakarta: Pustaka Pelajar. 2008.

Kaswan. Pelatihan dan Pengembangan; untuk meningkatkan kineja SDM. Bandung: Alfabeta. 2013.

Kunartinah. Pengaruh Pendidikan dan Pelatihan, Pembelajaran Organisasi Terhadap Kinerja dengan KOmpetensi Sebagai Mediasi. Jurnal bisnis dan ekonomi (JBE), Vol. 17 No. 1, Maret 2010. ISSN: 1412-3126. 2010.

Muhammad Rakib, Arfina Rombe, Muchtar Yunus, Pengaruh Pelatihan dan Pengalaman Mengajar terhadap Profesionalitas Guru (Studi pada Guru IPS Terpadu yang Memiliki Latar Belakang Pendidikan dalam Bidang Pendidikan Ekonomi). Jurnal Ad'ministrare, Vol. 3 No. 2, 2016, h. 137-148

Mulyasa. Standar Kompetensi dan Sertifikasi Guru.Bandung: Remaja Rosdakarya

Mulyawan, B., Pengaruh Pelatihan dalam Pengalaman terhadap Peningkatan Kompetensi Profesional Guru, Jurnal Ilmiah Ilmu Sosial, Vol. 11 No. 1, 2012, h. 45-64.

Musfah Jejen. Peningkatan Kompetensi Guru: Melalui Pelatihan dan Sumber Belajar Teori dan Praktik. Jakarta: Kencana. 2011.

Saud Syaefudin Udin. Pengembangan Profesi Guru. Bandung: Alfabeta. 2013.

Sugiyono. Metode Penelitian Kuantitatif, Kualitatif, dan R\&D.Bandung: ALFABETA, cetakan ke-26. 2017.

UU Nomor 14 Tahun 2005 Tentang Guru dan Dosen. 